\title{
MOTIVES FOR CHOOSING STUDIES AS PREDICTORS OF CAREER PLANS OF TOURISM AND RECREATION STUDENTS
}

\author{
Jarosław Nadobnik, ${ }^{A, B, D, E}$ Michał Tarnowski, ${ }^{A, B}$ Maria Alicja Nowak ${ }^{A, B, C}$ \\ Faculty of Physical Culture and Health Promotion, University of Szczecin, Poland

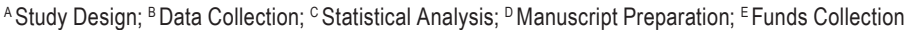 \\ Address for correspondence: \\ Jarosław Nadobnik \\ Faculty of Physical Culture and Health Promotion, University of Szczecin \\ Al. Piastów 40B, blok 6, 71-065 Szczecin, Poland \\ E-mail: jaroslaw.nadobnik@univ.szczecin.pl
}

\begin{abstract}
Ahstract The decreasing number of students at the Polish education system, the expectations of the labor market and the needs of employers are forcing the higher education system to make changes in programs and models of teaching. Upon graduation, a student should be prepared to meet the increasing demands of the employment market, which expects graduates to have high professional and language competencies, related to, among others, modern technologies.

The aim of the research conducted at the Faculty of Physical Culture and Health Promotion of the University of Szczecin was to ascertain the motives for the students' choice of studies in the field of Tourism and Recreation in the context of their career plans.

49 first-cycle students and 39 second-cycle students aged between 20 and 25 were examined. In the study the diagnostic survey was employed, with the use of the techniques of questionnaire, observation and interviews. For the statistical inference frequency of characteristics, chi-square test of independence and multiple correspondence analysis were applied.

It was found that the most important motives for studying Tourism and Recreation were interest in physical recreation, love of traveling, and desire to explore the world and disseminate a healthy lifestyle through active recreation. Students who chose the field of study consistent with their interests were planning to find jobs in a profession consistent with their education.
\end{abstract}

Key Worlls motives for studying, career plans, tourism and recreation

\section{Introduction}

Poland's accession to the European Union in 2004, apart from political and economic changes, had its consequences in Polish people's social life and education. Open borders and freedom to settle and earn income abroad have contributed over the years to significant migration movements of Polish citizens. Projections indicate that the population of our country - not only because of emigration - will be decreasing until 2035. As in other Western European countries, a favorable trend of lengthening the average life span of the population is observed in Poland, but it is accompanied by a change in the pattern of fertility, which includes a declining birth rate, fewer marriages being contracted and an increasing average age of women giving birth to their first child (Trzpiot, 2013). 
Human resources are a great asset of every country, and building a knowledge - based economy is a vital strategy of the European Union. Investing in education is a challenge which our society must face. The most important element of regional economy is technological knowledge and development. Employees and their creativity, entrepreneurship and level of knowledge and skills are a significant source of new knowledge (Łubkowska, Eider, 2014a). As far as higher education is concerned, Poland's EU accession resulted in the necessity to implement the so-called Bologna Process (Piasecka, 2014), which aimed at creating by 2010 a coherent European Higher Education Area through a system of ECTS credits, implementation of two-cycle studies, education quality control (systems of accreditation, certification, internal quality assurance systems), promotion of mobility programs for students and lecturers (Cieśliński, 2009) and promotion of lifelong learning (Nowak, 2008). It seems, therefore, that commencing first-cycle and later second-cycle studies is not only a possibility, but often a necessity (Ferenz, 2010), enabling a young person to find a suitable job more easily in future (Drozdek-Małolepsza, Michalski, Rodziewicz-Gruhn, 2010). Knowledge of foreign languages and confirmed additional professional competencies, for example related to handling modern technologies, significantly increase one's chances of being offered an attractive and rewarding position (Nadobnik, Trzeciak, 2011). The system of education is responsible for shaping the curriculum in such a way that it corresponds as much as possible to the modern labor market (Drozdek-Małolepsza, Michalski, 2011). Equally important is also monitoring of graduates' professional activity (Eider, 2009; Buchta, 2009; CzerepaniakWalczak, 2013; Radzińska, Nowak, Nowak 2016a, 2016b).

In the academic year 2010/11 the number of students at Polish universities amounted to more than 1.8 million. As a result of the ongoing demographic decline, in the years 2023-2025 the number of students will drop to approximately 1.25 million. It is anticipated that the relative decrease in the number of students in Poland will be one of the largest in Europe (Kwiek, 2015). The academic community in Zachodniopomorskie Province in 2007 numbered 79,027 people, while in the academic year 2012/2013 there were 62,470 students (a 20.95\% drop). A similar reduction in the number of students was reported at that time in the city of Szczecin - 21.04\% (Łubkowska, Eider, 2014b).

A drastic decrease in the number of students will not be experienced equally by all Polish universities. In the fields of medicine, law, information technology or philology of some languages, there are several times as many candidates as places available at particular faculties. Graduates from these fields of study are likely to find attractive offers in the labor market. Numerous job opportunities are an important determinant of high popularity of some (trendy) fields of study (Płowiec, 2010). Motives influencing young people's choice of study programs have for many years been the object of scientific inquiry (Łukaszewski, Doliński, 2002). A survey carried out in 1974 (Liberska, 1974) showed that for the majority of students in the early 1970s the main motive for commencing studies was the desire to gain more knowledge, while in 2004 (GUS, 2005) for nearly $70 \%$ of students under 30 years of age it was the possibility of finding employment after graduation. Further research published in 2013 (GUS, 2013) indicated that when choosing a course of study, candidates considered prospects of finding a job which would be in line with their interests.

At the Faculty of Physical Culture and Health Promotion of the University of Szczecin, students can, among others, choose the program in Tourism and Recreation, which is offered in two cycles. The undergraduate course with the general academic profile features the specialization of Animator of physical recreation and ecotourism (studies conducted jointly with the Faculty of Management and Economics of Services of the University of Szczecin), and in the Master's course with the practical profile students major in Health basis for tourism and recreation. 
The authors of this publication decided to try to answer the questions of, firstly, whether the students' decision to choose these fields of study was made in a thoughtful way, secondly, what their career plans are, and, thirdly, whether - in the assessment of the students - the study programs that they chose will help them in carrying out those plans. In light of the above-mentioned research results, the endeavor to find out whether undertaking the hardships of studying is a fully thought out action that facilitates the realization of one's aspirations related to their trained profession needs to be continued.

The aim of the study was therefore to ascertain the motives for the choice of studies in the field of Tourism and Recreation in the context of the students' career plans.

The following hypothesis was formulated:

The motives for choosing studies which are directly related to tourism and recreation are predictors of the students' career plans.

\section{Material and methods}

Since 2016 comprehensive research has been conducted at the Faculty of Physical Culture and Health Promotion among students majoring in Tourism and Recreation into the quality of education, motives for commencing studies and studying, assessment of the level of acquired knowledge, competencies and professional skills, and students' career plans. This paper presents results of the research related to motives for the choice of studies and career plans of students of Tourism and Recreation.

Among the respondents ( 49 students in the first and 39 in the second cycle) there were 69 women and 19 men aged 20 to 25, 54.4\% of whom were under 22 years of age. Students of Tourism and Recreation (hereinafter TAR) were mostly urban dwellers (79\%), $92 \%$ were single. $61.4 \%$ of the students graduated from comprehensive high school, $22.3 \%$ from technical high school (16.3\% did not answer). $75 \%$ of the respondents had experienced permanent or temporary employment. Over $95 \%$ of the subjects declared having left Poland before (at least several times). Respondents were characterized by a high level of physical activity: $88.9 \%$ of them reported practicing highperformance or recreational sport during their studies.

In the examination, the diagnostic survey was employed, with the use of the technique of questionnaire (Babbie, 2008), verified by the academic and research staff constituting the minimum required number of faculty members for the TAR program. The information obtained was supplemented with the results of observations and uncategorized interviews carried out among students. The qualitative and quantitative analysis was based on standard statistical methods: frequency of characteristics, chi-square test of independence and multiple correspondence analysis (van Burren, de Leuve, 2010). These analyses are available in the statistical software package Statistica 12 [StatSoft, inc. 2015 Statistica for Windows]. For the correlations tested, statistical significance at $p \leq 0.05$ was adopted. In the graphical interpretation of the results, Microsoft Excel was used, from the suite Office 2013 by Microsoft.

\section{Results}

For the respondents, the most important motives for commencing studies and studying Tourism and Recreation were interest in physical recreation (59.1\%), love of traveling and desire to explore the world $(54.8 \%)$ and desire to promote a healthy lifestyle through active recreation (50.9\%) (Table 1). The next two motives indicated by the subjects were desire to work in a recreational institution (46.1\%) and prospect of an interesting job connected with tourism and recreation, e.g. a tour organizer, a recreation animator, etc. (38.9\%). For about a third of the subjects 
the following were of great importance: the necessity of obtaining a higher education, desire to work in a tourism institution, e.g. in a travel agency, a hotel, etc., conviction of the attractiveness of the studies, and having personal predispositions to work with people.

Almost every fifth respondent pointed to the possibility of developing their own business in the field of recreation, their conviction of easiness of getting into university and studying, and desire to work in other institutions, not connected with tourism and recreation, The possibility to develop one's own undertaking in the field of tourism, personal (domestic and foreign) tourist experience, and perceived great opportunities for growth in the tourism industry were in turn important motives for about $15 \%$ of the subjects. $15.1 \%$ of the students were not sure about choosing this field of study, but had succumbed to the persuasion of their friends, acquaintances or parents. Few respondents indicated motives associated with a lower cost of living in comparison with other cities, experience in qualified tourism, and conviction of high social prestige attached to the profession of specialist in the field of tourism and recreation.

Table 1. Motives for choosing studies and studying Tourism and Recreation in relation to the cycle of studies and sex (independence $x^{2}$ test)

\begin{tabular}{|c|c|c|c|c|c|}
\hline \multirow{3}{*}{ Motives for choosing studies and studying Tourism and Recreation } & \multicolumn{2}{|c|}{ Study cycle } & \multicolumn{2}{|c|}{ Sex } & \multirow{2}{*}{$\begin{array}{c}\text { Total } \\
(88)\end{array}$} \\
\hline & $\begin{array}{c}1 \\
(n=49)\end{array}$ & $\begin{array}{c}\| \\
(n=39)\end{array}$ & $F(n=69)$ & $M(n=19)$ & \\
\hline & \multicolumn{5}{|c|}{$\%$} \\
\hline Interest in physical recreation & 59.2 & 59.0 & 58.0 & 61.1 & 59.1 \\
\hline Love of traveling and desire to explore the world & 63.3 & 46.2 & 53.6 & 61.1 & 54.8 \\
\hline Desire to disseminate a healthy lifestyle through active recreation & 53.1 & 48.7 & 46.4 & 72.2 & 50.9 \\
\hline Desire to work in a recreational institution & 40.8 & 51.3 & 42.0 & 55.6 & 46.1 \\
\hline Prospect of an interesting job (tour organizer, recreation animator, etc.) & 36.7 & 41.0 & 40.6 & 27.8 & 38.9 \\
\hline Necessity of obtaining a higher education & 44.9 & 23.1 & $30.4^{*}$ & $55.6^{*}$ & 34.0 \\
\hline Desire to work in a tourism institution (travel agency, hotel etc.) & 28.6 & 38.5 & 30.4 & 38.9 & 33.6 \\
\hline Conviction of the attractiveness of the studies & 32.7 & 30.8 & 31.8 & 33.3 & 31.8 \\
\hline Having predispositions to work with people (e.g. tourists) & 28.6 & 33.3 & 34.8 & 16.7 & 31.0 \\
\hline Possibility of developing one's own business in the field of recreation & 16.3 & 28.2 & 20.3 & 22.2 & 22.3 \\
\hline Conviction of easiness of getting into university and studying & 28.6 & 10.3 & $15.9^{*}$ & $38.9^{*}$ & 19.5 \\
\hline Desire to work in other institutions & 22.4 & 12.8 & 21.7 & 5.6 & 17.6 \\
\hline Possibility of developing one's own business in the field of tourism & 24.5 & 7.7 & 14.5 & 27.8 & 16.1 \\
\hline Personal tourist experience (foreign) & 16.3 & 15.4 & 14.5 & 22.2 & 15.9 \\
\hline Great opportunities for development in the tourism industry & 18.4 & 12.8 & 15.9 & 16.7 & 15.6 \\
\hline Personal tourist experience (domestic) & 20.4 & 10.3 & 15.9 & 16.7 & 15.4 \\
\hline Persuasion of friends, acquaintances, parents & 22.4 & 7.7 & $17.4^{*}$ & $11.1^{*}$ & 15.1 \\
\hline Lower cost of living in comparison with other cities & 14.3 & 5.1 & 10.1 & 11.1 & 9.7 \\
\hline Experience in qualified tourism & 8.2 & 10.3 & 8.7 & 11.1 & 9.3 \\
\hline Conviction of high social prestige of this occupation & 4.1 & 2.6 & 4.4 & - & 3.4 \\
\hline
\end{tabular}

${ }^{*}$ Statistical significance at $p \leq 0.05$ was adopted.

No differences in the motives for the choice of studies were observed in the first-cycle or second-cycle students of TAR. However, in the analysis of relationships between certain factors unrelated directly to the selected program 
of study (necessity of obtaining a higher education, conviction of easiness of getting into university, persuasion of friends or family) and sex, statistically significant dependences were found (in each case $p \leq 0.05$ for the $x^{2}$ test) (Figure 1).

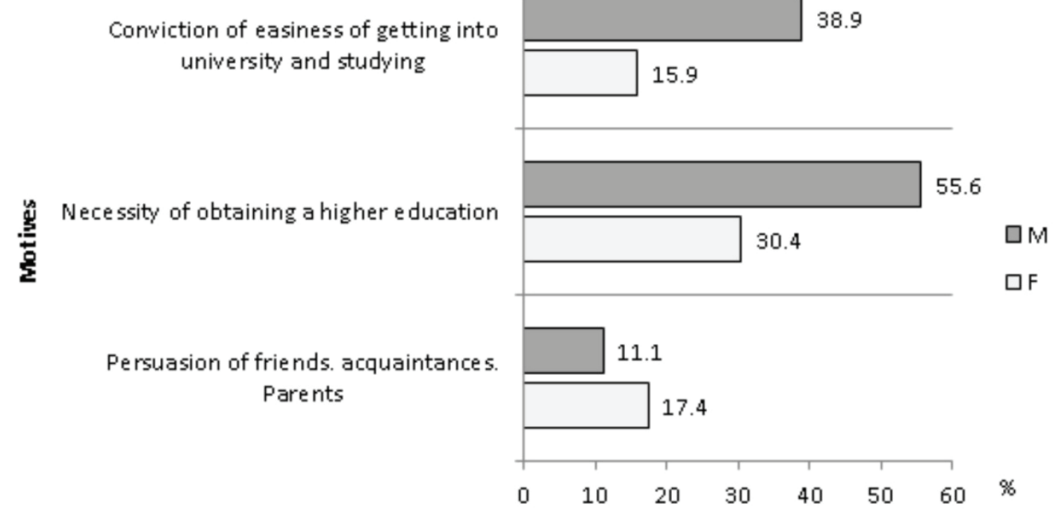

* Statistical significance at $p \leq 0.05$ was adopted. Source: own research.

Figure 1. Selected motives of students for commencing studies in the field of TAR (independence $x^{2}$ test)

The respondents reported on their career plans which they would like to carry out after completing the TAR studies (Figure 2). First-cycle students most often indicated: desire to work in a recreational institution (31.8\%), in a tourism institution (25\%), in a holiday resort (21.5\%), and in another profession related to physical culture (17\%).

Career prospects in the opinions of students in the second cycle of the TAR studies were different. $46.6 \%$ of the second-cycle students did not have any plans for future employment. The same proportion (46.6\%) intended to work in a profession unrelated to the field of study. About $44 \%$ of the prospective Masters of Arts considered permanent emigration and obtaining additional education ( $44.3 \%$ and $43.2 \%$ resp.). $41 \%$ of the second-cycle TAR students planned to work in other institutions connected with tourism and recreation, and the same number of them did not see a chance of finding a job in their acquired profession. Living abroad temporarily, working in a profession connected with physical culture or in a holiday resort was mentioned by approximately $30 \%$ of the subjects.

Statistically significant correlations were found between career plans and the cycle of study in which the respondents were (Figure 3). First-cycle students more often planned to work in recreational institutions ( $p \leq 0.05$ for the $x^{2}$ test) and slightly more often in tourism institutions ( $p \leq 0.05$ for the $X^{2}$ test). Second-cycle students more often associated their career plans with employment in a holiday resort ( $p \leq 0.05$ for the $x^{2}$ test), wanted to work in a profession not connected with their field of study ( $p \leq 0.05$ for the $x^{2}$ test), desired to obtain additional education ( $p \leq 0.05$ for the $x^{2}$ test) or planned to live abroad permanently ( $p \leq 0.05$ for the $\chi^{2}$ test). Second-cycle students did not have any plans for their future careers many times more often than their first-cycle counterparts $(p \leq 0.05$ for the $\chi^{2}$ test) $(46.6 \%$ and $1.2 \%$ resp.). 


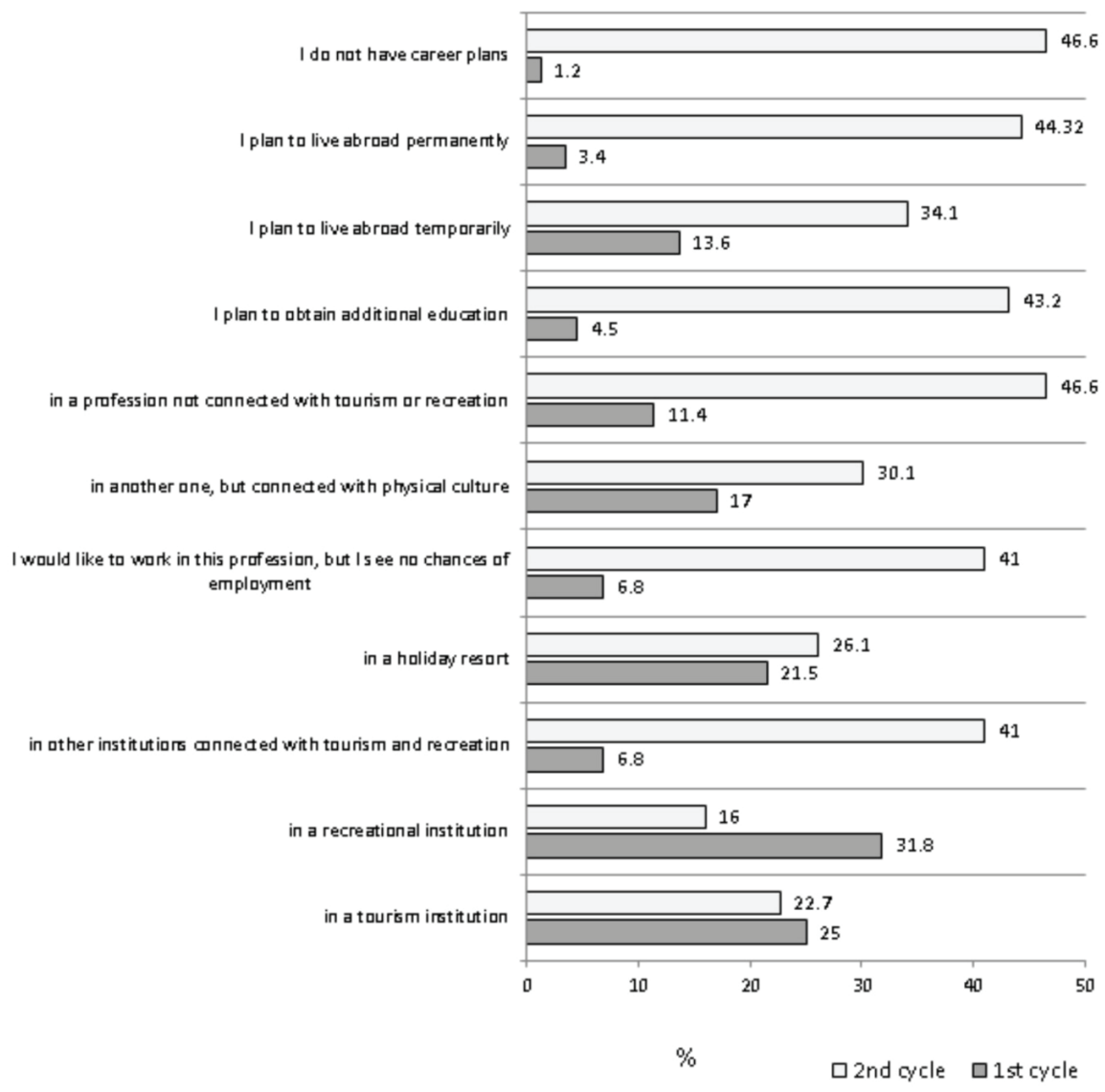

Figure 2. Respondents' career plans in relation to the cycle of study (\%). Source: own research

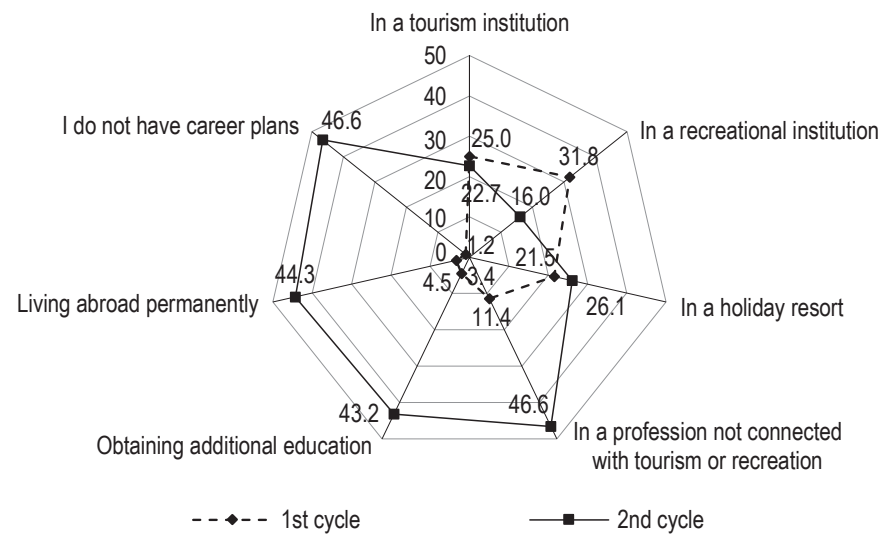

* Statistical significance at $p \leq 0.05$ was adopted. Source: own research.

Figure 3. Respondents' career plans with respect to the cycle of study (independence $x^{2}$ test) 


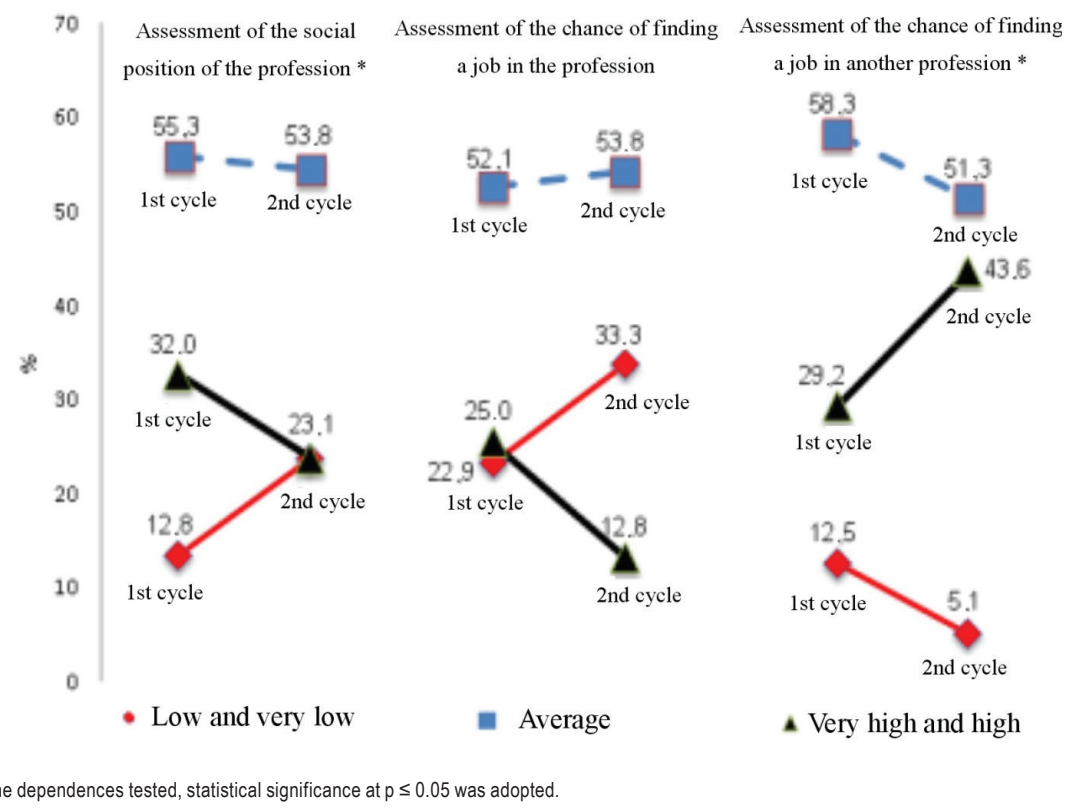

Figule 4. Assessment of the social position of a TAR-related profession, and the chance of finding a job in this profession or in a different one, not connected with TAR, made by the respondents - first and second-cycle students (independence $X^{2}$ test)

The prestige of the profession of specialist in the field of tourism and recreation in the opinion of students in both the first and second cycle of study was at an average level (55.3\% and $53.8 \%$ resp.) (Figure 4). $12.8 \%$ of the first-cycle students and $23.1 \%$ of the second-cycle students rated the social position of the profession as low and very low, while $32 \%$ of students in the first cycle and $23.1 \%$ of those in the second cycle considered it to be high and very high. First-cycle students were characterized by a higher assessment of the social position of the profession which they were trying to acquire ( $p \leq 0.05$ for the $x^{2}$ test).

Students in the first and second cycles of study did not differ significantly about the assessment of the chances of finding employment as a specialist in the field of tourism and recreation. Average and low ratings dominated.

A statistically significant correlation was found between the perceived chances of finding a job in another profession and the cycle of study ( $p \leq 0.05$ for the $x^{2}$ test). Second-cycle students much more often saw the chance of finding a job in another profession ( $43.6 \%$ and $29.2 \%$ resp.), although both groups mainly assessed it as average.

Associations between the motives for the choice of a study program which were directly linked to the interest in tourism and recreation and career plans and the respondents' cycle of study were presented comprehensively on the basis of multiple correspondence analysis (Figure 5) in conjunction with the results of the independence $X^{2}$ test (Table 1, Figure 2, 3). Two dimensions were selected (first and second), which explained $42.51 \%$ of the total value of $X^{2}$. 


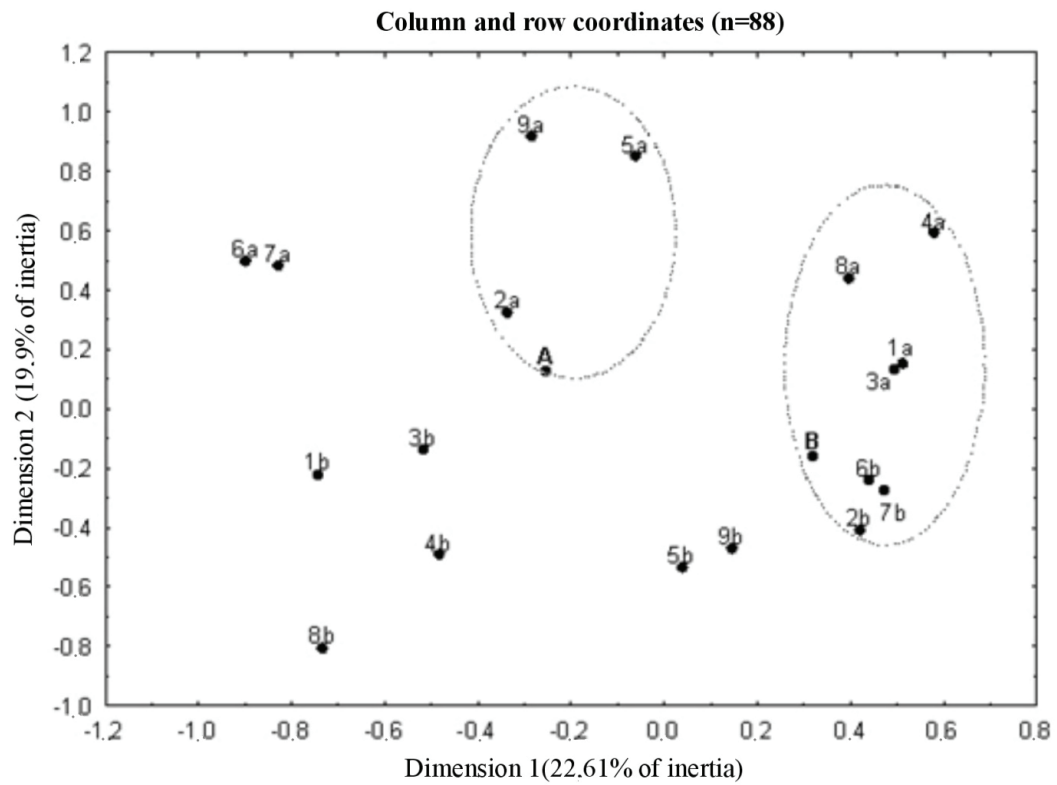

Figure 5. Relationships between the motives for the choice of a study program which were directly connected with the field of study and career plans and the subjects' cycle of study (MCA)

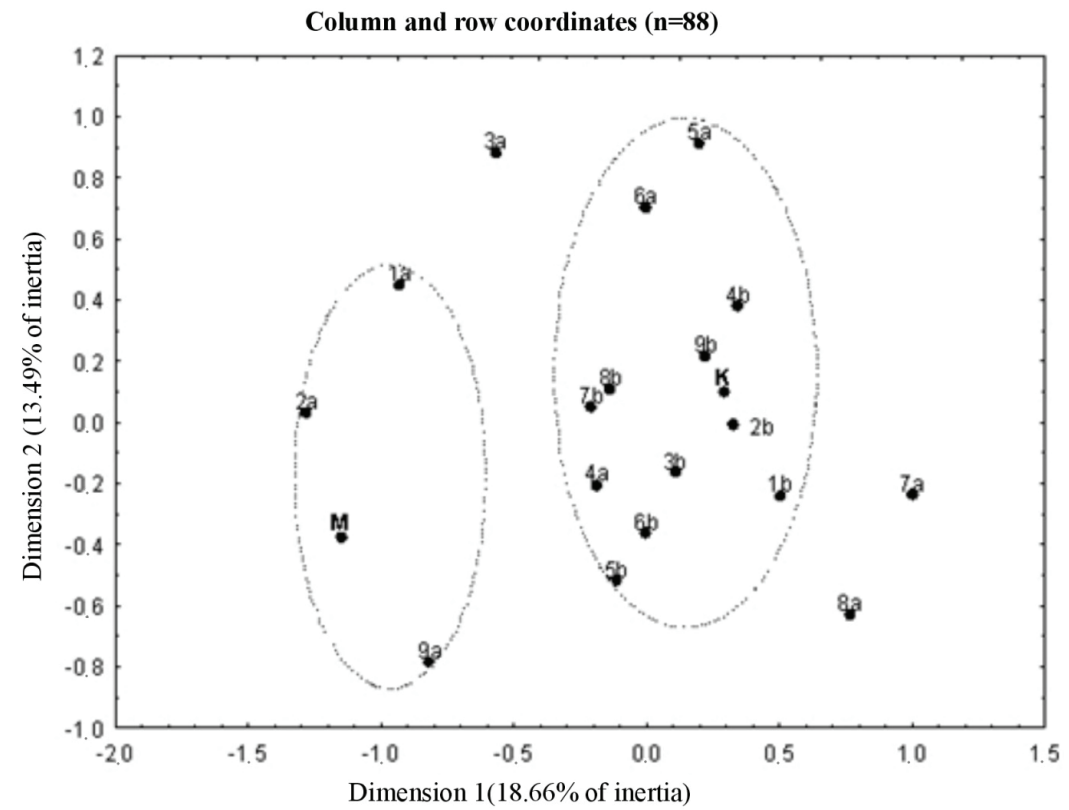

Figure $\boldsymbol{G}$. Relationships between the motives for the choice of a study program which were not directly connected with the field of study and career plans and the subjects' sex (MCA) 
In a graphical analysis of the results of the correspondence analysis in relation to two dimensions, the first cycle (A) and the second cycle of study (B) were distinguished. Students in the first cycle of the TAR program (A) chose this field because they were interested in traveling (2a) and having an interesting job (5a). They also would like to work in holiday resorts in the future (9a). For those studying in the second cycle (B) the main motives were their interest in physical recreation (1a) and the possibility of working in the area of physical recreation (4a). These subjects clearly associated their career plans with physical recreation (8a).

The respondents who were motivated to undertake the studies by their interest in employment in tourism (6a) and planned to work in an occupation connected with tourism (7a) occupied peripheral location.

Among both the first-cycle (A) and the second-cycle students (B) of TAR, there was a group of people who did not report motives for the choice of the program which were directly connected with this field of study ( $1 b, 3 b$, $4 b, 5 b)$, and did not see their future in the occupation of specialist in the area of tourism and recreation (8b, 9b).

Associations between the motives for the choice of a study program which were not directly linked to the interest in tourism and recreation and career plans and the respondents' sex were presented comprehensively on the basis of multiple correspondence analysis (Figure 6) in conjunction with the results of the independence $x^{2}$ test (Table 1, Figure 2, 3). The dimensions selected (first and second) explained $32.15 \%$ of the total value of $X^{2}$.

In a graphical analysis of the results of the correspondence analysis, a group of females (F) and males (M) were distinguished. Women $(F)$ less often reported motives not related to the field of study ( $1 b, 2 b, 3 b)$. They mainly based their career plans to the desire to work in recreation (4a), tourism (5a) and in holiday resorts (6a). For men (M) who chose this program of study in order to obtain any kind of higher education (1a), being also driven by the easiness of studying (2a), an important element in their career plans was to obtain additional education (9a). Peripheral location was occupied by the respondents who decided to study TAR at the suggestion of the closest people (3a) and associated their career plans with work in another profession (7a) or settling abroad permanently (8a).

\section{Discussion}

According to information provided by the Central Statistical Office in 2012 concerning the path of education and professional situation of Poles, the proportion of university students who declared compliance of the field of study which they had entered with their interests amounted to $53 \%$ for the entire country (GUS, 2013). In the case of TAR at the Faculty of Physical Culture and Health Promotion in Szczecin, students declared their interest in physical recreation at the level of $59.1 \%$, which may suggest high compliance of the undertaken study program with personal preferences of the respondents. Further education or willingness to obtain additional qualifications after graduation were declared, according to the same findings by the Central Statistical Office, by $20 \%$ of students in the whole country, while for the students of TAR at FPCHP surveyed in 2016, the proportion was $4.5 \%$ in first-cycle program and $43.2 \%$ in second-cycle program. These results indicate the necessity of continued research into the causes of disparities between students in the first and second cycles in their perception of the need for further education and acquiring new professional skills (Nadobnik, 2014).

In 2013, the proportion of people aged between 18 and 24 interested in going abroad to work amounted to over $60 \%$ (Kowalczuk, 2013). In the present study, the desire to go abroad to work was reported by $34.1 \%$ of secondcycle students and only $13.6 \%$ of first-cycle students. Perhaps so few first-cycle students showed willingness to leave the country because they were waiting with the decision about possible emigration until the completion of 
Master's studies. It is also possible, however, that the reasons are more complex: second-cycle students, who often already have some work experience, have a different assessment of the socio-economic situation and their chances of finding employment in Poland. This problem also requires constant monitoring.

The findings of the present study clearly show that further functioning of the study program of Tourism and Recreation at FPCHP requires actions aimed at reorganization, modification of the learning content, and enrichment of the educational process with competencies enabling TAR graduates to increase their chances of success on the labor market. According to the report "Barometer of professions", published in 2015 in cooperation with the Ministry of Family, Labor and Social Affairs and coordinated by the provincial labor offices (Bruzda, 2015), there is a large surplus of travel agency staff and tourist service organizers in relation to potential jobs in West Pomeranian Province and the neighboring provinces. A relative balance is observed however between vacancies and the number of tourist guides, tour leaders, professional culture animators and event organizers, including recreational, tourist and sports events.

Bearing in mind the above information concerning the labor market in West Pomeranian Province and the neighboring provinces, it is worth taking a look at the offer of FPCHP addressed to the students of TAR. Its aim is to develop key competencies of future graduates under the European Social Fund "OPERATIONAL PROGRAMME KNOWLEDGE - EDUCATION - DEVELOPMENT" (POWR.03.01.00-IP.08-00-PRK/16). The main effect of the project launched in 2017 is to be the students' acquisition of professional qualifications related to their field of study, raising qualifications connected with entrepreneurship, supplementation of language competencies in professional practice. The project encompasses specialized training and workshops featuring diplomatic protocol, event management, study visits, certified Nordic Walking course, and others.

Very good results and numerous achievements of the offered study program were confirmed by winning twice the first place in the rankings of Polish higher education institutions holding programs in tourism-related fields in 2015 and 2016, as well as the second place in the category "Public schools - scientific potential" (according to the trade magazine "Wiadomości Turystyczne" (Travel News) No. 4/2016). In their evaluation, the committees took into account and gave a large number of points for the scientific potential of schools, practical preparation of students for their profession, as well as studying conditions. Using innovative methods of effective education of students in the area of social competence and social capital deserves attention, for example group exercises in a rope park (Łubkowska, Tarnowski, 2015). The place of FPCHP of the University of Szczecin among the best educating universities in tourism-related fields in the whole country can be an additional motivation for potential candidates interested in the area of tourism and recreation, as well as for those who wish to obtain professional competencies in broadly understood physical culture.

As shown, motives directly related to the field of study can be predictors of taking a job in one's learned profession. Given the successes and achievements of the Faculty, the expectations of employers and the needs of the labor market, the program of study is worth promoting in the local environment in order to reach the largest possible number of candidates and convince them to study at the Faculty, showing the achievements and opportunities for development. 


\section{Conclusions}

1. The most often reported motives for commencing studies in the field of Tourism and Recreation were the students' interest in physical recreation, love of traveling and desire to explore the world, need to promote a healthy lifestyle through physical recreation and desire to work in a recreational institution.

2. The first-cycle students most often reported being interested in traveling and interesting jobs associated with it, however in the future they would like to work in holiday resorts. For those studying in the second cycle, the main motives for commencing studies were their interests in physical recreation and the possibility of working in the physical recreation area. Their career plans were clearly linked to physical recreation.

3. Women, more often than men, associated their career plans with their desire to work in recreation, tourism or a holiday resort. Men, for whom it was important to obtain additional education, more often reported that they had chosen the program in order to obtain any kind of higher education, being also driven by their opinion of the easiness of studying TAR.

\section{References}

Babbie, E. (2008). Podstawy badań społecznych. Warszawa: Wydawnictwo Naukowe PWN.

Bruzda, A. (2015). Barometr zawodów 2016 raport podsumowujący badanie w województwie tódzkim. Kraków: Wojewódzki Urząd Pracy.

Buchta, K. (2009). Quality of education from the prospective of a student of University of Physical Education. Pol. J. Sport Tourism, 16, 39-48.

Cieśliński, R. (2009). Uczelniany system jakości kształcenia - założenia a praktyka w kontekście procesu bolońskiego. Pol. J. Sport Tourism, 16, 135-142.

Czerepaniak-Walczak, M. (2013). Autonomia w kolorze sepii w inkrustowanej ramie KRK. O procedurach i treściach zmiany w edukacji akademickiej. In: M. Czerepaniak-Walczak (ed.), Fabryki dyplomów czy universitas? (pp. 29-54). Kraków: Wydawnictwo Impuls.

Drozdek-Małolepsza, T., Michalski, C., Rodziewicz-Gruhn, J. (2010). Jakość kształcenia w Akademii im. Jana Długosza w Częstochowie w opinii studentów kierunku wychowanie fizyczne. In: B. Sitarska, K. Jankowski, R. Droba (eds.), Studia wyższe z perspektywy rynku pracy (pp. 149-157). Siedlce: Wydawnictwo Akademii Podlaskiej.

Drozdek-Małolepsza, T., Michalski, C. (2011). Jakość kształcenia w Akademii im. Jana Długosza w Częstochowie w opinii absolwentów studiów I stopnia kierunku wychowanie fizyczne. In: B. Sitarska, K. Jankowski, R. Droba (eds.), Jakość kształcenia w szkole wyższej wobec wyzwań współczesności (pp. 159-166). Siedlce: Wydawnictwo Uniwersytetu Przyrodniczo-Humanistycznego.

Eider, J. (2009). Physical education faculty in Western Pomerania. Zeszyty Naukowe Uniwersytetu Szczecińskiego, 583, Prace Naukowe Instytutu Kultury Fizycznej, 26, 57-72.

Ferenz, K. (2010). Edukacja całożyciowa człowieka w świetle zadań rozwojowych. In: M. Kowalski, A. Olczak (eds.), Edukacja w przebiegu życia. Kraków: Oficyna Wydawnicza Impuls.

GUS, (2005). Ścieżki edukacyjne Polaków. Warszawa.

GUS, (2013). Wybory ścieżki kształcenia a sytuacja zawodowa Polaków. Warszawa.

Kraśniewski, A., Próchnicka, M. (2013). Benchmarking procesu wdrażania Krajowych Ram Kwalifikacji w polskich uczelniach. Warszawa: Oficyna Wydawnicza Politechniki Warszawskiej.

Kraśniewski, A. (2004). Proces Boloński dokąd zmierza europejskie szkolnictwo. Warszawa: Ministerstwo Edukacji Narodowej i Sportu.

Kwiek, M. (2015). Uniwersytet $w$ dobie przemian. Instytucje $i$ kadra akademicka $w$ warunkach rosnącej konkurencji. Warszawa: Wydawnictwo Naukowe PWN.

Łubkowska, W., Eider, J. (2014a). Uczelnie wyższe Szczecina jako potencjał regionu w aspekcie kształtowania innowacyjności. Handel Wewnętrzny, 5 (352), 123-137.

Łubkowska, W., Eider, J. (2014b). Kapitał ludzki województwa zachodniopomorskiego w procesach rozwoju innowacyjnego regionu. Handel Wewnętrzny, 5 (352), 107-122. 
Łubkowska, W., Tarnowski, M. (2015). Wykorzystanie parków linowych w edukacji jako formy kształtowania kompetencji społecznych studentów kierunku turystyka i rekreacja. Zeszyty Naukowe Wyższej Szkoły Bankowej we Wrocławiu, 15 (6), 775-786.

Łukaszewski, W., Doliński, D. (2002). Mechanizmy leżące u podstaw motywacji. In: J. Strelau (ed.), Psychologia. Podręcznik akademicki. Psychologia ogólna (pp. 441-468). Gdańsk: Wydawnictwo GWP.

Nadobnik, J., Trzeciak, J. (2011). Oczekiwania pracodawców dotyczące umiejętności obsługi komputera w świetle wybranych ofert zatrudnienia na lubuskim rynku pracy. In: G. Andrzejewski, W.A. Sysło (eds.), Edukacja techniczna dla rynku pracy (pp. 39-43). Gorzów Wlkp.: Wydawnictwo Naukowe Państwowej Wyższej Szkoły Zawodowej.

Nadobnik, J. (2014). Oczekiwania studentów turystyki i rekreacji w zakresie nauczanych treści przedmiotu „technologie informacyjne”. In: N. Dębowska, M. Walachowska, N. Starik (eds.), Edukacja międzykulturowa w warunkach kultury globalnej. Od rozważań definicyjnych do praktycznych zastosowań. Tom 2 (pp. 355-358). Poznań: Wydawnictwo Wyższej Szkoły Bezpieczeństwa.

Nowak, M. (2008). Aktywność fizyczna w prozdrowotnym stylu życia kobiet. Poznań: Wydawnictwo Akademii Wychowania Fizycznego.

Olczak, M. (ed.) (2010). Edukacja w przebiegu życia od dzieciństwa do starości (pp. 28-45). Kraków: Wydawnictwo Impuls.

Piasecka, A. (2014). Systemy zapewnienia jakości kształcenia w polskich szkołach wyższych w świetle Procesu Bolońskiego. Lublin: Wydawnictwo UMCS.

Płowiec, U. (2010). Innowacyjna Polska w Europie 2020: szanse i zagrożenia trwałego rozwoju. Warszawa: Polskie Wydawnictwo Ekonomiczne.

Radzińska, M., Nowak, L., Nowak, M.A. (2016a). Motives for commencing studies and expectations concerning professional competence in students who practice, used to practice or have never practiced sports, Central European Journal of Sport Sciences and Medicine, 13 (1), 37-47. DOI: 10.18276/cej.1-04.

Radzińska, M., Nowak, L., Nowak, M.A. (2016b). Satysfakcja z wyboru studiów a zamierzenia zawodowe studentów wychowania fizycznego, Prace Naukowe Akademii im. Jana Długosza, 15 (2), 109-124. DOI: http://dx.doi.org/10.16926/kf.2016.15.15.

Trzpiot, G. (2013). Prognozy ludności dla Polski - perspektywa logistyki społecznej. Studia Ekonomiczne, 175. Katowice: Wydawnictwo Uniwersytetu Ekonomicznego.

van Buuren, J., de Leeuw, J.V. (2010). Equality Constrains in Multiple Correspondence Analysis. Multivariate Behavioral Research, 27 (4), 567-583.

Sources used from websites:

http://eduentuzjasci.pl/badanie/599-talis (14.12.2016).

http://www.reformaprogramowa.men.gov.pl (15.10.2016).

http://dx.doi.org/10.16926/kf.2016.15.15 (15.10.2016).

Cite this apticle aS: Nadobnik, J., Tarnowski, M., Nowak, M.A. (2017). Motives for Choosing Studies as Predictors of Career Plans of Tourism and Recreation Students. Central European Journal of Sport Sciences and Medicine, 18 (2), 107-118. DOI: 10.18276/ cej.2017.2-11. 